\title{
ИСТОРИЯ
}

\section{М. Н. Богданов и Ц. Ж. Жамцарано о развитии капиталистических отношений в бурятском обществе в начале XX в.}

\section{Ширап Цыленович Цыдэнэ ${ }^{1}$}

\author{
${ }^{1}$ Институт монголоведения, буддологии и тибетологии СО РАН (д. 6, ул. Сахьяновой, \\ 670047 Улан-Удэ, Российская Федерация) \\ аспирант, младший научный сотрудник
}

iD 0000-0003-4207-5775. E-mail: tsydens@outlook.com

\author{
(c) КалмНЦ РАН, 2021 \\ (C) Цыдэнэ Ш. Ц., 2021
}

\begin{abstract}
Аннотация. В статье рассматриваются работы лидеров бурятского национального движения М. Н. Богданова и Ц. Ж. Жамцарано в контексте разработки проблемы развития капиталистических отношений в бурятском обществе в начале XX в. Цель исследования заключается в определении специфики в постановке проблемы развития капиталистических отношений у бурят в работах просветителей. Исследование основывается на оригинальных работах М. Н. Богданова и Ц. Ж. Жамцарано, опубликованных в начале XX в. Поставленные в статье задачи: охарактеризовать социальную и политическую позиции М. Н. Богданова и Ц. Ж. Жамцарано; выявить их точки зрения на проблему развития капиталистических отношений у бурят; выявить общее и особенное в их рассуждениях. Bblвoдbl. Из анализа работ бурятских просветителей выявлено, что проблема развития капиталистических отношений у бурят разрабатывалась в контексте национального и административного вопросов и более подробно - в направлении изучения социально-экономического развития бурят, степени социального расслоения и развития земельных отношений, которые были связаны с переселенческой кампанией. В отечественной историографии отмечается, что национальная интеллигенция рассматривала проблему на стадии первоначального накопления капитала, с присущими ей социальным расслоением и производственной дифференциацией. Отмечаем, что социальная и политическая принадлежность авторов не оказывала существенного, негативного влияния на ход их суждений, но обуславливала специфику взглядов. Несмотря на это, они находили общее в своих рассуждениях по каждому из направлений исследования.
\end{abstract}

Ключевые слова: капитализм, самосознание, правосознание, социальное расслоение, классовая борьба, поземельное устройство, методология

Благодарность. Статья подготовлена в рамках государственного задания — проект «Письменные традиции народов Байкальского региона в контексте истори- 
ко-культурного наследия России и Внутренней Азии» (номер госрегистрации: 121031000263-3).

Для цитирования: Цыдэнэ Ш. Ц. М. Н. Богданов и Ц. Ж. Жамцарано о развитии капиталистических отношений в бурятском обществе в начале ХХ в. // Монголоведение. 2021. T. 13. № 1. C. 41-55. DOI: 10.22162/2500-1523-2021-1-41-55

\title{
M. N. Bogdanov and Ts. Zh. Zhamtsarano: On the Development of Capitalist Relations in Buryat Society during the Early $\mathbf{2 0}^{\text {th }}$ Century
}

\author{
Shirap Ts. Tsydene
}

${ }^{1}$ Institute for Mongolian, Buddhist and Tibetan Studies, Siberian Branch of the RAS (6, Sakhyanova St., Ulan-Ude 670047, Russian Federation)

Postgraduate Student, Junior Research Associate

(iD) 0000-0003-4207-5775. E-mail: tsydens@outlook.com

(C) KalmSC RAS, 2021

(C) Tsydene Sh. Ts., 2021

\begin{abstract}
Introduction. The article considers works by leaders of the Buryat national movement M. N. Bogdanov and Ts. Zh. Zhamtsarano to provide insight into the issue of capitalist relations development in Buryat society during the early $20^{\text {th }}$ century. Goals. The article seeks to determine specific features of the problem formulation thereto traced in studies conducted by the mentioned scholars. The research analyzes articles of M. N. Bogdanov and Ts. Zh. Zhamtsarano published at the beginning of the $20^{\text {th }}$ century. The objectives set in the article are aimed at characterizing the social and political standpoints of M. N. Bogdanov and Ts. Zhamtsarano; revealing their attitudes to the problem of capitalist relations development among the Buryats; exploring general and special points in their reasoning. Conclusions. The study of socioeconomic development of the Buryats, including that of land relations, are associated with the resettlement campaign. Russian historiography notes that the ethnic intelligentsia considered the problem at the stage of the initial accumulation of capital with its inherent social stratification and manufacturing differentiation. It is also clear that the social and political affiliation of the authors had no significant negative impacts on the course of their judgments but did determine the specificities of their views. Despite this, they found common ground in their reasoning for each of the research areas.
\end{abstract}

Keywords: capitalism, self-consciousness, legal awareness, social stratification, class struggle, land structure, methodology

Acknowledgements. The reported study was funded by government assignment — project name 'Writing Traditions of the Peoples of the Baikal Region in the Context of Historical and Cultural Heritage of Russia and Inner Asia' (state reg. no. 121031000263-3).

For citation: Tsydene Sh. Ts. M. N. Bogdanov and Ts. Zh. Zhamtsarano: On the Development of Capitalist Relations in Buryat Society during the Early $20^{\text {th }}$ Century. Mongolian Studies (Elista). 2021. Vol. 13(1): 41-55. (In Russ.). DOI: 10.22162/2500-1523-2021-1-41-55 


\section{История}

\section{Введение}

Отечественная историография национального движения, лидеров этого движения и состояние бурятского общества в начале XX в. акцентирует внимание на влиянии капиталистических отношений на происходившие процессы. В этих условиях М. Н. Богдановым и Ц. Ж. Жамцарано рассматривалась проблема развития капиталистических отношений в бурятском обществе. При этом М. Н. Богданов в своих взглядах склонялся в сторону обрусителей; Ц. Ж. Жамцарано придерживался позиции национальной самоидентификации.

\section{Методы исследования}

В исследовании были применены исторический, сравнительный и типологический методы. Исторический метод был направлен на изучение связи между историческим временем и пространством, в котором пребывали авторы с ходом их рассуждений, так была обнаружена связь правительственных мероприятий и внутренних процессов в бурятском обществе со спецификой постановки проблемы развития капиталистических отношений среди бурят. Сравнительный и типологический методы комбинировались, благодаря этому были выявлены характерные черты в социально-политических позициях авторов, а затем результаты анализа авторских работ были типологизированы как три отдельных направления разработки проблемы в исследованиях авторов.

Капитализм и хозяйственное состояние бурят в трудах М. Н. Богданова и Ц. Ж. Жамцарано

В работе М. Н. Богданова «Бурятское возрождение» содержатся опасения: «не успеет ли раздавить нас всемогущий бог западно-европейской культуры — «капитал, который с выдворением в России новых форм жизни, мощными шагами пойдет вперед?» [Богданов 1907: 47]. Это опасение было вызвано пониманием силы рынка, который, по представлениям автора, был способен подчинить себе нужды любого [Богданов 1907: 49].

В другой статье М. Н. Богданов писал об общей беде русского и инородческого населения Иркутской губернии, где «капитал уже вырос за пределы национальных рамок» [Богданов 1906: 55].

Менее обеспокоен развитием капитализма Ц. Ж. Жамцарано, который в ответной серии статей «Народное движение бурят и его критика» понимает представления М. Н. Богданова о капитализме как о силе, нивелирующей все национальные различия, которая должна совершить капитализацию и пролетаризацию [Жамцарано 1907a: 17-18]. Жамцарано видит близость между трактовками капитализма М. Н. Богдановым и социал-демократами, хотя тут же подчеркивает, что не считает его партийным. Далее Ц. Ж. Жамцарано говорит о несостоятельности учения марксистов, ссылаясь на примеры национальных революций в Европе, и в самой судьбе России [Жамцарано 1907a: 18].

Размышлениям о нивелирующем наступлении капитализма Ц. Ж. Жамцарано противопоставил правосознание и самосознание: их развитие в бурятском обществе он объясняет, ссылаясь на докладную записку забайкальских бурят от 1905 г., указав в качестве причины «именно, пользование самоуправлением 
(подразумевается самоуправление по Уставу 1822 г.)ํ. когда не обладало им даже русское население, сделало то, что у забайкальских инородцев развилось как самосознание, так и правосознание, буряты самоопределились, как народность» [Жамцарано 1906: 170].

Об этих качествах гражданского общества, при рассмотрении существующей в начале XX в. системы управления иркутскими бурятами, так рассуждал его оппонент М. Н. Богданов: «это было не мертвое, шаблонное, чисто канцелярское дело, а живое, затрагивающее основы и существенные вопросы всего общественного быта» [Братский 1904: 133], при условии твердой позиции головы ведомства и уважения в инородной управе решений сугланов «везде в таких случаях вопросы, обсуждаемые на сугланах, возбуждают живейший интерес», так же автор приводит примеры эволюционного развития бурятского общественного строя через учреждение новых и функциональные изменения старых должностных лиц [Братский 1904: 133].

В другой статье М. Н. Богданова имеются указания на проявление самосознания бурят, выступивших перед русской администрацией в лице крестьянского начальника с проектом обустройства социальной и экономической жизни общества [Братский 1910: 75-80]. Правда, там же подчеркивается редкость таких случаев.

Тем не менее в размышлениях оппонентов имеется и общность взглядов на поиск причины национального подъёма в начале XX в., оба видят её в общественном укладе, который был закреплен статьями Устава от 1822 г., которые сделали возможным формирование в бурятах самосознания и правосознания. Эти неотъемлемые качества инициативного гражданского общества, казалось Ц. Ж. Жамцарано, могли уберечь бурят от худших проявлений капитализма [Жамцарано 1906: 170-171; Жамцарано 1907a: 19-20].

Однако ошибочно утверждать, что авторы пренебрегали материальной базой. Материальную, т. е. хозяйственную, опору социального переустройства просветители видели по-разному. Ц. Ж. Жамцарано в общинном землевладении и землепользовании видел опору национальной идентичности и экономического благосостояния бурят, против которого, по его мнению, были нацелены «все меры правительства с 1890 г., против той солидарности, единства.., которое делало бурят весьма стойкими» [Жамцарано 1906: 169].

Отсюда вывод, что Ц. Ж. Жамцарано не видел большую угрозу в нивелировании национальной идентичности бурят в капиталистических отношениях, при условии их верности собственным институтам, их усовершенствованию, которые уже продемонстрировали свою прочность в кризисных условиях. О них автор ведет речь в статье «О том, как развивались самосознание и правосознание сибирских инородцев-бурят», где описана борьба бурят за свой образ жизни [Жамцарано 1905: 3889-3890].

Размышления Ц. Ж. Жамцарано об этом образе жизни можно обобщить в его выражении: «все дела несутся всей общиной вместе» [Жамцарано 1906: $171]$.

По-другому думал М. Н. Богданов, который в своих статьях «Очерк бурятского хозяйства в Балаганском уезде» и «Очерк бурятского хозяйства в

${ }^{1}$ Устав «об управлении инородцев» от 22 июля 1822 г. 


\section{История}

Иркутской губернии» подводит читателя к мысли о переходном состоянии социально-экономического устройства бурят. Автор видел архаичные черты бурятского общества в неразвитости промыслов и приверженности к скотоводству. Буряты практически не вовлекались в промыслы, которые требовали длительного отлучения от домашнего хозяйства, оставаясь верными промыслам, «составляющим исконное занятие старожилов - охоте и звероловству» [Богданов 1908г: 60-61].

Положение скотоводства М. Н. Богданов оценил так: «даже в наиболее земледельческих (бурятских) ведомствах скотоводство играет большую роль, чем в наиболее скотоводческих русских волостях» [Богданов 1908г: 58]. Эти мысли подтверждаются им в статье «Иркутские буряты и землеустройство», здесь, вместе с подробной классификацией русского и бурятского населения, автор указал на более развитую хозяйственную группировку и высокую социальную дифференциацию русских [Богданов 1908г: 58].

М. Н. Богданов подчеркивает близость бурятского населения к природе, зависимость от неё, невовлеченность (бурят) в водоворот торгово-промышленной жизни края [Богданов 1908б: 42].

Доходы скотоводства в общем объёме М. Н. Богданов затрудняется определить, ссылаясь на отсутствие на этот счет источников, но смог указать на его пищевую направленность, приведя пример торгового сотрудничества бурят и русских скупщиков, последние распространяли бурятское мясо по всему Иркутску [Богданов 1908в: 42].

О масштабах этого сотрудничества М. Н. Богданов упомянул как об одном из наиболее важных источников продовольственного снабжения Иркутска, без которого город находился бы в тяжелом положении во время русско-японской войны.

В итоге Михаил Николаевич отметил особенности социально-экономического устройства бурят и определил его состояние как переходное и стремящееся к русскому типу крестьянского хозяйства, более предпочтительному для обустройства жизни в условиях нового века.

Заметки М. Н. Богданова о типе бурятского хозяйства и его связях с общим хозяйством региона, а именно - «местное население всюду приспособляется к этим (естественным) условиям и создает в каждом районе особый хозяйственный тип», говорят об этом переходе как о живом и вариативном процессе [Богданов 1908в: 42]. К схожим мыслям приходит и Ц. Ж. Жамцарано в статье «О правосознании бурят» [Жамцарано 1906: 175].

Живой характер этого хозяйства состоит в стремлении и действиях бурят по его развитию. Так, М. Н. Богданов упоминает о попытках ходатайствовать «об открытии школ с преподаванием «рационального скотоводства» [Богданов 1908г: 60].

Требование о развитии образования среди бурят фигурирует и в других статьях автора, в попытке организации 5-классного училища с преподаванием медицины, огородничества и рационального скотоводства [М. Б. 1908: 58].

Ходатайства об открытии школ сопровождались комментариями выборных бурятского самоуправления, что «лучше мы ничего не могли придумать» [Братский 1904: 133]. 
Получила предварение в специальном суглане проблема рационализации бурятского хозяйства «по вопросу об улучшении породы местного скота», где обсуждалось открытие по этому случаю «Особого общества», которое курировало бы данную работу [Богданов 1908в: 43].

Развив позицию о важности скотоводческого хозяйства бурят, ссылаясь на слова Дмитрия Клеменца о том, что «(буряты), где представляется возможность, разнообразят свой быт... новыми занятиями, вводят новые порядки, цель которых - обеспечить по возможности каждому правомерное пользование плодами своих трудов», Ц. Ж. Жамцарано заключает: «Невозможно вводить одинаковый порядок жизни, формы хозяйства» [Жамцарано 1906: 177178]. По мнению автора, куда лучше представить «единство в разнообразии... взаимное дополнение... путь, обещающий богатые результаты» [Жамцарано 1906: 177-178], там же рассматриваются примеры преимущества такого положения.

Также были упоминания о желании бурятских лидеров организовать собственное маслобойное производство на основании имеющихся продуктов сельского хозяйства, в особенности кожи [Жамцарано 1906: 171].

В контексте разнообразия производства также следует упомянуть о заметках М. Н. Богданова о росте среди бурятского населения разнообразия в потребностях, которые он объясняет влиянием русского населения. Русские ответственны за распространение земледелия среди бурят, и те в свою очередь вместе с успехами на этом поприще разворачиваются к рынку для реализации «продуктов полевого хозяйства на сторону» [Братский 1906: 285 ].

Таким образом, бурятские просветители выявили единую закономерность хозяйственного развития бурят в рационализации скотоводства, а также в повышении правосознания и самосознания бурятского общества, из чего можно заключить, что при оценке тенденции роста гражданственности бурят мнения бурятских лидеров не имеют существенных расхождений, однако трудно сказать то же самое при оценке материальной базы бурятского народа. М. Н. Богданов был настроен скептически по отношению к приверженности бурят к скотоводству, но подчеркивал правильность попыток его рационализировать [Богданов 1908г: 60]; Ц. Ж. Жамцарано считал, напротив, данный путь «улучшения и усовершенствования скотоводческо-кочевого хозяйства» основным [Жамцарано 1906: 177]. Такое положение вещей неудивительно, потому как оба автора относились к достаточно радикальному левому крылу национального движения, которое содержало внутренний конфликт «западников» и «народников», к первым принадлежал М. Н. Богданов, а ко вторым - Ц. Ж. Жамцарано.

Так бурятские просветители в целом понимают неизбежность наступления капитализма. Но подчеркивают необходимость быть правильно подготовленными к вовлечению в капиталистические отношения - социально, политически и экономически. Неподготовленность в этих сферах, по мнению М. Н. Богданова, могла бы привести бурят к глубокому хозяйственному кризису, избежать которого можно при условии приближения бурятского жизненного уклада к укладу русского крестьянства. Это должно было обеспечить главное - усложнение и дифференциацию бурятского хозяйства. 


\section{История}

Для Ц. Ж. Жамцарано этот вопрос стоит менее выпукло, в социальной и политической сферах исследователь более основательно полагается на проявленные бурятами самосознание и правосознание, в хозяйственном смысле на традиционные способы вести хозяйство в плане видов занятий и способов их организации, хотя и рассуждает о правильности развития более сложных видов производства.

\section{О социальном расслоении в бурятском обществе}

Другой не менее важный момент, связанный с развитием капиталистических отношений, это вопрос социального расслоения. Одним из первых в отношении коренных народов Сибири эту тему исследовал М. С. Ольминский при рассмотрении земельных отношений в якутской общине, в которой, по мнению М. С. Ольминского, имелись признаки социального расслоения в имущественном разрыве родовой знати и обычных общинников (цит. по: [Шейнфельд 1973: 84]).

Спустя годы этому процессу дал описание С. В. Бахрушин, который указал на установившуюся благодаря Уставу 1822 г. возможность для якутских родовых предводителей расширять свои владения через договор с бедными общинниками, обязуясь уплачивать за них ясак, взамен завладевая земельными наделами последних [Бахрушин 1929: 91].

Эти примеры напоминают заметки М. Н. Богданова о «разложении» крупнейших бурятских ведомств в конце 1880-х гг.: «вопрос об образовании более мелких ведомств на место прежних решался самими бурятами, вскоре... образовались две партии: «старая партия», стоявшая за прежний порядок со степными думами, и «новая партия», настаивавшая на необходимости ведения нового порядка» [Братский 1904: 131].

Однако необходимо признать, что здесь речь идёт в первую очередь об административном управлении. Но, несмотря на это, нужно подчеркнуть особенность этих дискуссий, в ходе которых в обязательном порядке должен был производиться земельный передел, и этот вопрос должен был стоять наравне с вопросами административного управления и власти. По нашим соображениям, только их комбинация могла привести бурят к частым конфликтам и даже применению оружия в борьбе друг с другом, вне зависимости от возраста, что было подробно описано М. Н. Богдановым [Братский 1904: 132].

Несмотря на подверженность системы управления бурят влиянию капиталистических отношений, трудно говорить об отдаленности должностных лиц от общинников, учитывая их выборность. Однако это не мешало им осуществлять кредитную деятельность среди своих соплеменников за немалый процент, за счет личных денег и даже общественных [Братский 1904: 141]. Помимо этого, лица, причастные к управлению, использовали административный статус в финансовых сделках, как «возможность более успешно взыскивать долги», а также практиковали «так называемое, общественное ручательство» [Братский 1904: 142]. Под этим понимаются кредиты, которые брались на имя ведомства, данными средствами должностные лица могли распоряжаться достаточно вольно. Однако М. Н. Богданов не спешит обличать бурятских администраторов, подчеркивая отсутствие у бурят иных вариантов кредита на 
более приемлемых условиях. Важность кредита подчеркивается и в других статьях как «неотложные нужды» [Богданов 1908в: 45].

О социальной напряженности и расслоении также упоминал Ц. Ж. Жамцарано, указав на нахождение бурятского имущего класса в, «быть может, не преднамеренном союзе с шаманами», на обрядах которых, по мнению автора, богатые «наживают десятки и сотни тысяч рублей ежегодно» [Жамцарано 19076: 17].

Кроме того, М. Н. Богданов снова указывает на условие, которое может благоприятствовать развитию социального расслоения, а затем и напряженности, это бессистемность суда в бурятских ведомствах, где мера наказания за проступок определялась «от личности как судьи, так и провинившегося», способности последнего ответить на наказание, которое он может счесть несправедливым [Братский 1904: 148].

Другими словами, исследователи-просветители указывают на влияние капитала на традиционные институты, проникновение товарно-денежных отношений в общественное самоуправление бурят. Во-первых, когда должностные лица могли использовать свое положение для укрепления личного хозяйства через учреждение новых поборов и, возможно, расширение земельных владений за счет беднейших соплеменников. Во-вторых, они же использовали свое положение для проведения финансовых операций за счет общественных средств под различными предлогами. Однако ни Ц. Ж. Жамцарано, ни М. Н. Богданов не акцентируют внимание на классовости взаимоотношений в бурятском обществе, а их заметки о некоем противостоянии не носят систематического характера. А из имеющихся заметок можно сделать вывод, что в социальном расслоении как явлении, где существует эксплуатация, авторы видят отрицательное влияние на бурят. Однако как таковой процесс расслоения в бурятском обществе они видят в зачаточном состоянии, из которого еще не вырос классовый вопрос.

\section{О влиянии землеустроительной кампании царского правительства на бурят}

Учитывая привязанность бурятского населения к земле, их зависимость от неё и её значение в хозяйственном и социальном планах, одним из наиболее важных для бурят является вопрос земельной и переселенческой политики царского правительства в начале XX в. Он нашел отражение в работах М. Н. Богданова и Ц. Ж. Жамцарано.

М. Н. Богданов в статье «Иркутские буряты и землеустройство» продолжает говорить о влиянии русских на бурятское общество. Он приводит мнение о переселенцах из западной части России как о носителях товарно-денежных отношений, что «почти 3/4 приписного поселенческого населения волостей... находится в отсутствии», т. е., как правило, находились в отлучке от мест приписки и были заняты различными промыслами в качестве наемных работников [Богданов 1908б: 44].

Ранее об этом говорил И. А. Гурвич, в будущем революционер. Он обнаружил тенденцию по расширению переселенческой кампании на примере переселения крестьян на Алтай, которые были не обеспечены средствами для от- 


\section{История}

крытия своего хозяйства. Так, они выступали в роли элемента, расслаивавшего крестьянство, носителя капиталистических отношений, как в форме батрачества, так и в кредитных связях со старожилами [Гурвич 1889: 80, 85].

Жизнь отсутствующих поселенцев проходила в соответствии с запросами рынка. Данную картину дополняет исследование рыбопромыслового хозяйства сибирских крестьян А. Г. Шлихтера, где обнаружена прямая параллель между ростом производительности хозяйств и расширением практики привлечения вольнонаёмного труда [Шлихтер 1916: 44].

Так авторы сошлись во мнениях с марксистами о взаимовлиянии социальных и экономических процессов. Мнение Богданова о роли поселенцев подтверждается работами таких марксистов, как вышеупомянутые И. А. Гурвич («Переселение крестьян в Сибирь») и А. Г. Шлихтер («Экономическое положение крестьян Туруханского края»), которые на тот момент специализировались на подобных исследованиях.

Связь этих явлений с поземельным устройством бурят не так очевидна, однако обнаружена М. Н. Богдановым. В статье «Иркутские буряты и землеустройство» он разобрал порядок формирования и распределения земельных наделов землеустроительной и землеотводной компаниями, которые производились, основываясь на идее о равенстве русского и инородческого населения, по единому стандарту земельных наделов, что не могло обеспечить реальное равенство ввиду недоработок инструкций в части подсчета лиц, которым полагались бы наделы. В результате этих компаний буряты были вынуждены сократить поголовье скота ввиду неспособности его содержать в рамках срезанного надела, в конце работы автор заключил, что «для нас становится ясно, что формальное равенство... которое стремятся водворить на местах, в действительности неизбежно должно превратиться в самое вопиющее неравенство» [Богданов 1908б: 43-45].

В другой статье М. Н. Богданов указал на вторую причину сложившегося для бурят положения, подчеркнув естественную непригодность бурятских территорий для интенсивного земледелия в ограниченных наделах: «земля далеко не подобна холсту, который можно разрезать на куски любого размера». О них автор сказал так: «нельзя согнать людей в один угол... так же невозможно, создав искусственное земельное утеснение, заставить перейти к более интенсивным формам хозяйства» [Богданов 1908в: 40].

Эта позиция напоминает о понятии «относительного малоземелья», которое было проработано А. А. Кауфманом как ситуация, при которой население имеет нехватку земли ровно в такой степени, которая сподвигнет население улучшить инструменты качественного развития хозяйства, а не количественного. Так правительство формирует условия «относительного малоземелья» для бурят с целью обеспечить приемлемые условия русского переселенческого населения.

В заключение о переселенческой политике будет правильно процитировать слова М. Н. Богданова: «Если землеотводные работы будут и впредь вестись в тех же размерах и теми же приемами... то большой части бурятских улусов грозит полнейшее разорение» [Богданов 1908а: 32], тут же автор пришел к выводу о целенаправленных действиях правительства. 
В последнем замечании мнение М. Н. Богданова разделил Ц. Ж. Жамцарано [Жамцарано 1906: 174]. Однако его подход к земельному вопросу, хоть и был близок к позиции его оппонента, но представил более четкую критическую оценку политике правительства. Это заметно в его статьях: «К вопросу о правосознании бурят»; «О том, как развивалось самосознание и правосознание сибирских инородцев-бурят». Нельзя ошибиться, если указать на одну из причин такой позиции - активную вовлеченность автора к описываемым им событиям - и обнаружить другую в вышеупомянутых словах М. Н. Богданова о близости бурятского образа жизни к земле. Это у забайкальских бурят было заметно куда глубже и комбинировалось с существенными и трудными для них изменениями в административном управлении. Обобщить размышления Ц. Ж. Жамцарано можно его высказыванием: «подушевой или мелкообщинный надел не устроит, а разстроит хозяйство бурят» [Жамцарано 1906: 177]. По поводу действий правительства Ц. Ж. Жамцарано говорил: «меры, которые нарушили равновесие жизни, выбили бурят из колеи», а их результат автор определил так: «народ перестал быть хозяином в своем доме» [Жамцарано 1906: 178].

Таким образом, исследователи раскрыли взаимовлияние социальных и экономических процессов, с учётом политических действий правительства. М. Н. Богданов заключил, что все прибывавшие поселенцы являются носителями капиталистических, рыночных отношений. Ц. Ж. Жамцарано посвятил свои исследования административной стороне поземельного устройства, рассуждал о влиянии политики правительства на уклад жизни местного сообщества. Но оба автора не видели ничего позитивного в поземельном переустройстве в том виде, в котором оно производилось в то время.

Отдельные моменты из исследований подпадали под влияние личных взглядов автора. М. Н. Богданов занимал по большинству вопросов прогрессивную позицию, так называемую «западническую», хотя бывало, что эта приверженность подводила автора при рассмотрении противоположных взглядов. В статье «Бурятское возрождение», критикуя позиции Ц. Ж. Жамцарано о распространении буддизма среди иркутских бурят, он ссылается на разговоры с некими лицами из народа, и на основании этих частных примеров автор заключает, что существует «сильное противоламское течение», то же касается мнения о роли в этом процессе сотрудников учительской организации «Знамя Бурятского народа» и критики нового монголо-бурятского алфавита [Богданов 1907: 41].

Это создает впечатление о скоропалительности выводов М. Н. Богданова, некотором пренебрежении к темам, касающимся традиции, и прочему, что не соответствовало идеям М. Н. Богданова о развитии бурятского общества, на что и указывал Ц. Ж. Жамцарано, дав объяснение ошибке М. Н. Богданова [Жамцарано 1907в: 19]. Позицию М. Н. Богданова он обосновывал содержанием устава учительского общества, опубликованного в № 19 журнала «Сибирские вопросы». Однако в статье «Сибирское земство и инородцы», когда обсуждалась более понятная тема организации самоуправления, М. Н. Богданов вполне аргументированно критиковал проекты своих оппонентов [Богданов 1906: 52-57]. 


\section{История}

С другой стороны, Ц. Ж. Жамцарано проявляет увлеченность в ответных статьях, критикуя позиции М. Н. Богданова, когда начинает приводить в качестве аргументов труднореализуемые задачи, к примеру, сбыт товаров духовного производства бурят на рынки всех монгольских народов, в ответ на замечания о малости собственного рынка для бурятского производителя в условиях наступающего капитализма [Жамцарано 1907a: 20].

Другими словами, социальная и политическая позиция авторов, состоящая в принадлежности к политическим группам «западников» и «народников», по большому счету не отразилась на выводах Ц. Ж. Жамцарано и М. Н. Богданова, хотя и формировали методологическую позицию авторов. Ограничились эти вольности отдельными проявлениями в ходе острой полемики по вопросам жизнедеятельности бурятского общества, которые не касались напрямую проблемы развития капиталистических отношений у бурят. Исключением может быть пример, приведенный выше.

\section{Заключение}

Бурятские просветители Ц. Ж. Жамцарано и М. Н. Богданов сформировали собственный, специфический взгляд на проблему развития капиталистических отношений в бурятском обществе, которую они рассматривали в трех плоскостях: а) социально-экономического развития; б) степени социального расслоения; в) а также в плане земельных взаимоотношений у бурят. Причина отдельной разработки последнего вопроса заключается в условиях существования бурятского народа, а именно давлении со стороны правительства в рамках землеустроительной политики.

В социально-экономической плоскости авторы обнаружили единую тенденцию в развитии бурятского хозяйства в скотоводческой направленности. Однако оценивали они этот процесс по-разному. М. Н. Богданов говорил о переходном состоянии бурятского хозяйства, которое, по его мнению, приближалось к русскому типу крестьянского хозяйства. Этот процесс должен был положить конец вышеупомянутой тенденции; по мнению автора, переход был правильным, но до сих пор недостаточным. Причины этого перехода М. Н. Богданов видел в русском влиянии, в распространении среди бурят земледелия, которое ответственно за разнообразие потребностей и поворот бурят к рынку в стремлении реализовать продукты сельского производства на стороне. Ц. Ж. Жамцарано этот процесс видел иначе, он подчеркивал перспективу и правильность планов бурят по рационализации и дальнейшему развитию ими своего скотоводческого хозяйства, опору своим словам автор нашел в доводах авторитетного ученого Д. А. Клеменца о преуспевающих скотоводческих хозяйствах Европы. Другими словами, авторы на основании существующего состояния бурятского хозяйства рассуждали о моделях лучшего хозяйственного устройства для менее болезненного вовлечения бурят в товарно-денежные отношения.

Вместе с тем авторы увидели вторую тенденцию в развитии бурятского общества, называли они её по-разному, но обобщенно представляли как национальный подъем бурятского народа в начале XX в., а причины этого подъёма они определили идентично - в развитии правосознания и самосознания бу- 
рятского общества. Именно на эти качества обращено внимание авторов при оценке возможности бурятского общества должным образом реагировать на вызовы времени, способности быстро и эффективно перестроить социальноэкономический уклад в соответствии с новыми условиями.

В социальном расслоении бурятского общества исследователи обнаружили влияние капитала на самоуправление бурят и формирование имущих социальных групп, которые эксплуатировали беднейших соплеменников, а местами преодолели национальные рамки. Однако проработанного представления о классовости взаимоотношений в бурятском обществе авторы не имеют, а Ц. Ж. Жамцарано и вовсе говорил о коммунистическом характере бурятского общества. Глубже рассуждал М. Н. Богданов, когда определил во все прибывающих русских переселенцах носителей товарно-денежных отношений, обнаружил в бессистемности суда раздражитель социальных отношений и в финансовых операциях должностных лиц видел влияние рынка. Сошлись авторы в одном - в оценке нежелательности таких явлений, как эксплуатация одного над другим в бурятском обществе. Так социальное расслоение у бурят они видят в зачаточном состоянии, из которого еще не вырос классовый вопрос. Имеющиеся процессы социального расслоения обуславливались русским влиянием и несовершенством административной системы.

В земельных отношениях просветители обратили внимание на два момента. Первый - внутренний, где М. Н. Богданов дал описание бурятской жизни в условиях проведения административных реформ 1880-х гг. в Иркутской губернии, когда уровень борьбы в бурятском обществе дошел до открытых столкновений. По нашим соображениям бессистемность суда, злоупотребления тайшей могли дать такой результат при условии, что административный передел должен был означать и земельный передел. Однако говорить о конфликте внутри бурятского общества между имущими и неимущими классами в борьбе за землю преждевременно, хотя примеры такого неравенства у коренных народов приводили в своих исследованиях марксисты. Вместе с тем интересно привести заметку из современного исследования Л. М. Дамешека, Б. Ц. Жалсановой и Л. В. Кураса: «таким образом... для многих зажиточных бурят был открыт доступ к высшим должностям степного самоуправления» [Дамешек, Жалсанова, Курас 2013: 274]. Другими словами, эта реформа укрепила положение капитала в бурятском обществе.

Второй - внешний - заключается в рассмотрении влияния землеустроительной и переселенческой компаний на жизнь бурятского населения. Авторы солидарны в негативной оценке правительственной политики, но М. Н. Богданов глубже связал социальный и экономический процессы через роль переселенцев в распространении капиталистических отношений, в том числе на бурят. Ц. Ж. Жамцарано в свою очередь сосредоточился на защите традиционного уклада жизни и предоставлении доказательств о неправильности позиции правительства, которая заключалась в отрицании возможности коллективных способов организации производства развиваться в товарно-денежных отношениях. Общинную собственность на землю правительство считало архаичным и несовместимым с понятием частной собственности. Так было раскрыто вза- 


\section{История}

имовлияние социальных и экономических процессов, с учётом политических действий правительства.

Так просветители в целом понимают неизбежность наступления капитализма. Но подчеркивают необходимость быть правильно подготовленными к вовлечению в товарно-денежные отношения в социальном, политическом и экономическом планах. Неподготовленность в этих сферах, по мнению М. Н. Богданова, могла бы привести бурят к глубокому хозяйственному кризису, избежать которого можно при условии приближения бурятского жизненного уклада к укладу русского крестьянства. Что, по мнению автора, должно было обеспечить главное - усложнение и дифференциацию бурятского хозяйства.

Для Ц. Ж. Жамцарано этот вопрос стоит менее выпукло, в социальной и политической сферах исследователь более основательно полагается на проявленные бурятами самосознание и правосознание, в хозяйственном смысле на традиционные способы вести хозяйство в плане видов занятий и способов их организации. Хотя он рассуждает о правильности развития более сложных видов производства.

Исходя из выводов и рассуждений, сделанных М. Н. Богдановым и Ц. Ж. Жамцарано, можно заключить, что авторы исследовали бурятское общество в условиях зарождающихся капиталистических отношений, которые развивались среди бурят ввиду как объективных внутренних изменений в жизненном укладе, так и субъективных изменений в ходе внешних правительственных мер по организации бурятской жизни. Данное заключение пересекается с оценкой В. А. Ватина, исследователя-марксиста, об уровне развития капитала в Сибири, которая звучала так: «Это эпоха первоначального накопления капитала... период, не закончившийся до сих пор» (цит. по: [Шейнфельд 1973: 127]).

Схожие мысли о недостаточной развитости хозяйственных отношений и общественном расслоении выражал В. Н. Соколов (цит. по: [Шейнфельд 1973: 111]).

Таким образом, бурятские просветители в процессе внутренней конкуренции разрабатывают собственный взгляд на проблематику развития капиталистических отношений применительно к исследованию бурятского общества.

\section{Литература}

Бахрушин 1929 - Бахрушин С. В. Сибирские туземцы под русской властью до революции 1917 года // Советский север. 1929. № 1. С. 66-97.

Богданов 1906 - Богданов М. Н. Сибирское земство и инородцы // Сибирские вопросы. 1906. № 2. С. 52-57.

Богданов 1907 - Богданов М. Н. Бурятское возрождение // Сибирские вопросы. 1907. № 3. C. $38-50$.

Богданов $1908 \mathrm{a}$ - Богданов М. Н. Землеотводные операции и буряты Иркутской губернии // Сибирские вопросы. 1908. № 35-36. С. 26-32.

Богданов $1908 \sigma$ - Богданов М. Н. Иркутские буряты и землеустройство // Сибирские вопросы. 1908. № 31-32. С 38-50.

Богданов 1908в - Богданов М. Н. К вопросу о Бурятском многоземелье // Сибирские вопросы. 1908. № 39-40. С. 35-46. 
Богданов 1908г - Богданов М. Н. Очерк бурятского хозяйства в Иркутской губернии // Сибирские вопросы. 1908. № 29-30. С. 52-63.

Братский 1904 - Братский М. К характеристике общественного строя Иркутских бурят // Сибирский сборник. Прил. «Восточное обозрение». 1904. С. 109-162.

Братский 1906 - Братский М. Очерк бурятского хозяйства в Балаганском уезде Иркутской губернии // Сибирские вопросы. 1906. № 2. С. 277-288.

Братский 1910 - Братский М. Среди бурят Кудинского ведомства // Сибирские вопросы. 1910. № 45-46. С. 75-80.

Гурвич 1889 - Гурвич И. А. Переселение крестьян в Сибирь. М.: Тип. А. Левенсон и К., 1889, 147 c.

Дамешек, Жалсанова, Курас 2013 - Дамешек Л. М. Жалсанова Б. Ц. Курас Л. В. История органов местного самоуправления бурят в XIX - начале XX в. / отв. ред. Б. В. Базаров, Л. М. Дамешек, Б. Ц. Жалсанова, Л. В. Курас. Иркутск.: Изд-во ИГУ, 2013. $503 \mathrm{c}$.

Жамцарано 1905 - Жамиарано Ц. Ж. О том, как развивались самосознание и правосознание сибирских инородцев - бурят // Право. 1905. № 49-49. С. 3885-3897.

Жамцарано 1906 - Жамиарано Ц. Ж. О Правосознании бурят // Сибирские вопросы. 1906. № 2. С. 167-184.

Жамцарано 1907а - Жамичарано Ц. Ж. Народное движение бурят и его критика // Сибирские вопросы. 1907. № 25. С. 15-21.

Жамцарано $1907 б$ - Жамиарано Ц. Ж. Народное движение бурят и его критика // Сибирские вопросы. 1907. № 24. С. 15-20.

Жамцарано 1907в - Жамизарано Ц. Ж. Народное движение бурят и его критика // Сибирские вопросы. 1907. № 23. С. 17-20.

М. Б. $1908-$ М. Б. Культурные начинания среди бурят Иркутской губернии // Сибирские вопросы. 1908. № 23-24. С. 57-60.

Шейнфельд 1973 - Шейнфельд М. Б. Историография Сибири (конец XIX - начало ХХ в.). Красноярск: Изд-во Краснояр. пед. ин-та. 1973. 399 с.

Шлихтер 1916 - Шлихтер А. Г. Экономическое положение крестьян Туруханского края. Ч-2. Экономический анализ рыбопромыслового хозяйства по данным статистического подворно-бюджетного исследования крестьянских хозяйств Туруханского края. Материалы по исследованию р. Енисея в рыбопромысловом отношении. Упр. земледелия и гос. имуществ Енис. губ. Вып. 8. Красноярск: тип. б. М. И. Абалакова. 1916. 298 с.

\section{References}

Bakhrushin S. V. Siberian natives under the Russian government: before the Revolution of 1917. Sovetskiy sever. 1929. No. 1. Pp. 66-97. (In Russ.)

Bogdanov M. N. An essay of Buryat economy in Irkutsk Governorate. Sibirskie voprosy. 1908. No. 29-30. Pp. 52-63. (In Russ.)

Bogdanov M. N. The issue of Buryat lands revisited. Sibirskie voprosy. 1908. No. 39-40. Pp. 35-46. (In Russ.)

Bogdanov M. N. Buryat revival. Sibirskie voprosy. 1907. No. 3. Pp. 38-50. (In Russ.)

Bogdanov M. N. Irkutsk Buryats and land management. Sibirskie voprosy. 1908. No. 31-32. Pp. 38-50. (In Russ.)

Bogdanov M. N. Land acquisition operations and Buryats of Irkutsk Governorate. Sibirskie voprosy. 1908. No. 35-36. Pp. 26-32. (In Russ.)

Bogdanov M. N. Siberian zemstvo and natives. Sibirskie voprosy. 1906. No. 2. Pp. 52-57. (In Russ.)

Bratsky M. Among Buryats of Kuda Principality. Sibirskie voprosy. 1910. No. 45-46. Pp. 75-80. (In Russ.) 


\section{История}

Bratsky M. An essay on Buryat economy in Balagansk District of Irkutsk Governorate. Sibirskie voprosy. 1906. No. 2. Pp. 277-288. (In Russ.)

Bratsky M. Irkutsk Buryats: characteristics of social structure. Sibirskiy sbornik. 1904. Pp. 109-162. (In Russ.)

Dameshek L. M., Zhalsanova B. Ts., Kuras L. V. Self-Governing Bodies of the Buryats, $19^{\text {th }}$ - Early $20^{\text {th }}$ Centuries: A History. B. Bazarov (ed.). Irkutsk: Irkutsk State University, 2013. 503 p. (In Russ.)

Gurvich I. A. Resettlement of Peasants to Siberia. Moscow: A. Levenson \& Co, 1889. 147 p. (In Russ.)

M. B. Cultural initiatives among Buryats of Irkutsk Governorate. Sibirskie voprosy. 1908. No. 23-24. Pp. 57-60. (In Russ.)

Sheinfeld M. B. Historiography of Siberia: Late $19^{\text {th }}-$ Early $20^{\text {th }}$ Centuries. Krasnoyarsk: Krasnoyarsk Pedagogical Institute, 1973. 399 p. (In Russ.)

Shlikhter A. G. The Economic Situation among Peasants of Turukhansk Region. Part 2: Economic Analysis of Fishery Industry according to Statistical Household Budget Research of Peasant Farms in Turukhansk Region. Materials for the Fishery Study of the Yenisei River. Krasnoyarsk: M. Abalakov, 1916. 298 p. (In Russ.)

Zhamtsarano Ts. Zh. Buryat people's movement and its criticism. Sibirskie voprosy. 1907. No. 25. Pp. 15-21. (In Russ.)

Zhamtsarano Ts. Zh. Buryat people's movement and its criticism. Sibirskie voprosy. 1907. No. 24. Pp. 15-20. (In Russ.)

Zhamtsarano Ts. Zh. Buryat people's movement and its criticism. Sibirskie voprosy. 1907. No. 23. Pp. 17-20. (In Russ.)

Zhamtsarano Ts. Zh. On legal awareness of the Buryats. Sibirskie voprosy. 1906. No. 2. Pp. 167-184. (In Russ.)

Zhamtsarano Ts. Zh. Siberian natives - Buryats: the shaping of self-consciousness and legal awareness revisited. Pravo. 1905. No. 49-49. Pp. 3885-3897. (In Russ.) 